\title{
FISSOLDHIMINE, A NOVEL SKELETON ALKALOID FROM FISSISTIGMA OLDHAMII
}

\author{
Jin-Bin WU, ${ }^{\text {a }}$ Yih-Dih CHENG, ${ }^{\text {a }}$ Shen-Chu KUO, ${ }^{\text {a }}$ Tian-Shung WU, ${ }^{\text {b }}$ Yoichi IITAKA, \\ Yutaka EBIZUKA ${ }^{\mathrm{d}}$ and Ushio SANKAWA ${ }^{* \mathrm{~d}}$ \\ Institute of Pharmaceutical Chemistry, China Medical College, ${ }^{a} 91$ Hsueh-Shih Road, Taichung, \\ Taiwan, Republic of China, Department of Chemistry, National Cheng-Kong University, ${ }^{b}$ Taiwan, \\ Republic of China, Nishi-Tokyo Science University, ${ }^{c} 2525$ Yatsuzawa Azaotsukoshi, Uenoharamachi, \\ Kitatsurugun, Yamanashi 409-01, Japan, and Faculty of Pharmaceutical Sciences, The University \\ of Tokyo, ${ }^{d}$ 7-3-1 Hongo, Bunkyo-ku, Tokyo 113, Japan
}

A new alkaloid of hydro-oxadiazine with a four-ring fused structure has been isolated from Fissistigma oldhamii (Memsl.) Merr. (Annonaceae) and named fissoldhimine (1), the structure of which was solved by X-ray analysis. NMR spectra were assigned based on the established structure, and its possible biogenesis is also discussed.

KEYWORDS alkaloid; hydro-oxadiazine; Fissistigma oldhamii; Annonaceae; fissoldhimine

Fissistigma oldhamii (Hemsl.) Merr. (Annonaceae) is a perennial shrub which is distributed mainly in southern China and Taiwan. The herb has been used as a folk medicine in southern China and Taiwan for the treatment of sciatica and arthritis, and anti-inflammatory and anti-tumor purposes.". 2) Several aporphine alkaloids have so far been isolated and identified from the plant collected in Taiwan ${ }^{2,3)}$ In a preliminary bioassay, its methanol extract showed anti-platelet aggregation activity and its constituents were investigated in the plant material collected in Taichung, Taiwan. ${ }^{2)}$ Methanolic extract of fresh stems $(4 \mathrm{~kg})$ was fractionated with hexane, and the methanolic fraction was treated with 5\% hydrochloric acid solution. Insoluble material was removed and acidic solution was made alkaline with ammonia to $\mathrm{pH} 8.5$. An alkaline solution was then extracted with chloroform to obtain a basic fraction which contained alkaloids with anti-platelet aggregatory activity. In a previous paper we reported the isolation and identification of five alkaloids, xylopine and calycinine of aporphine type, O-methylmoschatoline of oxoaprophine type, and two morphinandienone alkaloids, $\mathrm{N}$-methyl-2,3,6-trimethoxymorphinandien-7-one and N-nor-2,3,6-trimethoxymorphinan-dien-7one. ${ }^{2)}$ The alkaline aqueous solution was further extracted with butanol to obtain more polar alkaloids. Butanolic fraction was further fractionated with a HP-20 column with water-methanol, and an alkaloid-containing fraction was again fractionated with a LH-20 column chromatography with methanol to afford an alkaloid as colourless rhombic crystals of mp 234-6 from methanol (ca. $100 \mathrm{mg}$ ). Following spectral investigations have revealed that the isolated alkaloid is a novel structure and named fissoldhimine (1).

FAB MS gave a molecular ion at $\mathrm{m} / \mathrm{z} 279(\mathrm{M}+1)$ and a strong fragment peak at $\mathrm{m} / \mathrm{z} 235$ corresponding to a $\mathrm{M}^{+}-\mathrm{C}_{3} \mathrm{H}_{7}$ fragment, which gave a molecular formula of $\mathrm{C}_{11} \mathrm{H}_{15} \mathrm{~N}_{4} \mathrm{O}_{2}$ in highresolution MS ${ }^{4)} \mathrm{NMR}$ spectra indicated the presence of one methyl, seven methylenes, four methines and two carbons at the carbonyl region. COSY NMR spectrum proved the presence of propyl group linked to a methine which gave signals at lower fields $\left({ }^{13} \mathrm{C} \delta 62.9,{ }^{1} \mathrm{H} \delta 5.47\right)$, indicating this methine carbon linked with two hetero-atoms coresponding to a partial structure A where two Xs denote $\mathrm{O}$ or $\mathrm{N}$. Another methine also gave signals at very low fields $\left({ }^{13} \mathrm{C} \delta 65.6,{ }^{1} \mathrm{H} \delta 4.85\right)$, and the 
<smiles>[X]C([X])CCC</smiles>

A<smiles>[X]C([X])C(C)C([X])C</smiles>

B

NMR spectra gave the partial structure $B$, in which three $\mathrm{Xs}$ are hetero-atoms. These spectral investigations indicate that fissoldhimine (1) possesses a molecular formula

of $\mathrm{C}_{14} \mathrm{H}_{22} \mathrm{~N}_{4} \mathrm{O}_{2}$.

Fissoldhimine (1) gave crystals suitable for X-ray analysis from methanol. The crystal was monoclinic with space group of $\mathrm{P} 2_{1} / \mathrm{n}$ containing 4 molecules in a unit cell. The space group indicates that fissoldhiine (1) is a racemate. The dimensions of the cell are $\mathrm{a}=20.982$ (10) $\AA, \mathrm{b}=$ 13.025 (8) $\AA, c=5.128$ (3) $\AA, \beta=96.70(5)^{\circ}, V=1392 \AA^{3}$. A total of 2571 reflections between a range of $6^{\circ}-156^{\circ}$ were collected on a Philips PW1100 difractometer. Structure was solved by direct method (MULTAN), and refinement was performed by block-diagonal-matrix least-squares method. $20 \mathrm{C}, \mathrm{N} \cdot \mathrm{O}$ atoms were refined with anisotropic temperature factor, and $22 \mathrm{H}$ atoms were found on the difference electron-density map and located at the calculated positions. A final $\mathrm{R}$ value with isotopic temperature factor for $\mathrm{H}$ and anisotropic temperature factors for $\mathrm{C}, \mathrm{N}, \mathrm{O}$ was 0.07 . Only one hydrogen bond was found between the neighboring molecules, between imino- $\mathrm{NH}$ and carbonyl-O. ${ }^{13} \mathrm{C}$ and ${ }^{1} \mathrm{H}$ NMR were assigned according to the structure solved by X-ray analysis. ${ }^{5)}$ Due to the complicated couplings ${ }^{1} \mathrm{H}$ NMR, coupling constants cannot be defined, and most of them were represented as multiplets.
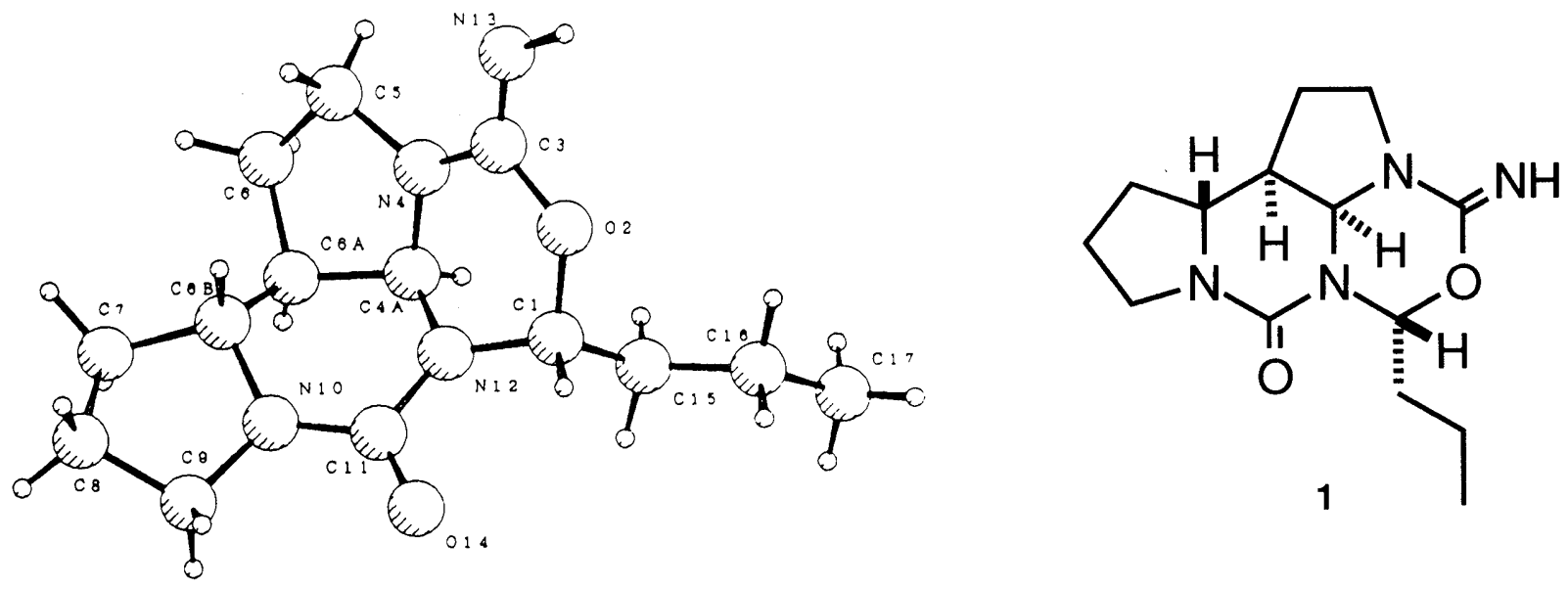

\section{Drawing of Fissoldhimine (1) with Coordinates of X-Ray Analysis}

Since the skeleton of fissoldhimine (1) is quite novel, it is of interest to discuss its possible biogenesis. Oxidation of putrescine (3) that is derived from the decarboxylation of ornithine (2) gave 4-aminobutanal (4), which is spontaneously cyclized to give $\Delta^{1}$-pyrrorideine (5). It is expected to dimerize easily between an imine (5) and an enamine (5') to give a dimeric pyrrorideine (6). $\mathrm{N}$ carbamoyl transfer from carbamoyl phosphate gives a carbamoyl intermediate (7), which undergoes cyclization to give a diazinone (8) of cyclic urea structure. Further carbamoyl transfer gives another carbamoyl intermediate (9), and following aminoacetalization with butyraldehyde affords fissoldhimine (1). Since butanol was used to extract basic compounds from alkaline aqueous solution, there would be a possibility that final aminoacetalization was caused chemically with butyraldehyde present in butanol, and a true natural product produced by the plant may be a 
carbamate (9). Further study is required to elucidate this question. Biological activities of fissolidhimine (1) is under investigation.

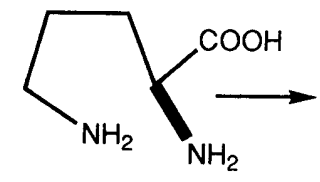

2<smiles>NCCCCN</smiles>

3<smiles>C[C@H](N)CCO</smiles>

4<smiles>CC1CC2CCC1N2C=C1CCCN1</smiles>

$5^{\prime}$<smiles>C1=NCCC1[C@H]1C=NCC1</smiles>

$\mathrm{H}_{2} \mathrm{PO}_{4} \mathrm{CONH}_{2}$

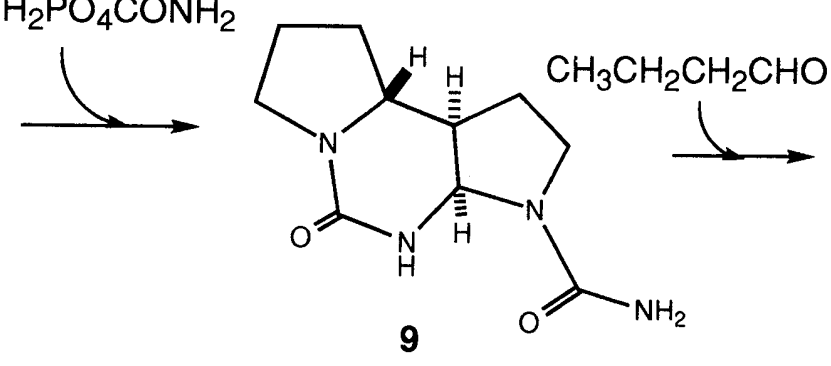

A Possible Biogenesis of Fissoldhimine (1)

\section{REFERENCES AND NOTES}

1) "Zhon Yao Dai Zi Ten (Encyclopedia Chinese Materia Medica)", ed. by Jiang Su New Medical College, Shanghai Science and Technology Publisher, 1977, p. 758.

2) Jin-Bin Wu, Yih-Dih Cheng, Nien-Yung Chin, Shung-Chien Juang, Sheng-Chu Kuo, Planta Medica, 59, 179 (1993).

3) Sheng-Teh Lu, Yang-Chang Wu, Heterocycles, 20, 813 (1983).

4) FAB-MS m/z $279[M+1]$. High Resolution MS m/z 235, obs. 235.1203; calcd for $\mathrm{C}_{11} \mathrm{H}_{15} \mathrm{~N}_{4} \mathrm{O}_{2}$ 235.1105.

5) ${ }^{13} \mathrm{C}-\mathrm{NMR}\left(\mathrm{CDCl}_{3}\right) \delta: 13.5\left(\mathrm{CH}_{3}, \mathrm{C}-17\right), 17.9\left(\mathrm{CH}_{2}, \mathrm{C}-16\right), 22.8\left(\mathrm{CH}_{2}, \mathrm{C}-8\right), 24.4\left(\mathrm{CH}_{2}, \mathrm{C}-6\right)$, $32.0\left(\mathrm{CH}_{2}, \mathrm{C}-7\right), 37.8\left(\mathrm{CH}_{2}, \mathrm{C}-15\right), 41.6\left(\mathrm{CH}_{2}, \mathrm{C}-5\right), 41.9(\mathrm{CH}, \mathrm{C}-6 \mathrm{a}) .45 .4\left(\mathrm{CH}_{2}, \mathrm{C}-9\right), 54.5$ (CH, C-6b), 62.9 (CH, C-1), 65.6 (CH, C-4a), 153.0 (C, C-3), 152.3 (C, C-11). ${ }^{1} \mathrm{H}-\mathrm{NMR}$

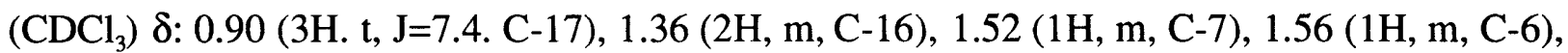
1.63 (2H, m, C-8), 1.66 (2H, m, C-15), 2.22 (1H x 3, m, C-7, C-6, C-6a), 3.14 (1H, m, C-6b), 3.36-3.59 (2H x 2, m, C-5, C-9), $4.85(1 \mathrm{H}, \mathrm{d}, \mathrm{J}=9.2 \mathrm{~Hz}, \mathrm{C}-4 \mathrm{a}), 5.47$ (1H, q like, C-1), 5.60 (1H, d, J=3.6 Hz, N-13). 